\title{
Determinants of Job Satisfaction among Management Faculty Academics in Selected Public Universities in the Western Province of Sri Lanka
}

\author{
G.D.N. Perera and L. Wijewardene \\ Senior Lecturers, Department of Human Resource Management and Business Communication Unit, Faculty of \\ Management \&Studies Commerce, University of Sri Jayewardenepura, Sri Lanka
}

\begin{abstract}
The mainobjective of this study was to investigatedeterminants of job satisfaction amongManagement Faculty Academics in three selected public universities in the Western Province. The dependent variable wasjob satisfaction and the independent variable consists of determinants ofjob satisfaction such as pay, workload, recognition, work autonomy and working environment.This study employed a quantitative approach. In collecting data, a self-structuredquestionnairewith a 5-point Likertscalewas used to collect responses from threepublic universities in Western Province. The study was conducted by using a random sampling technique and the sample consisted of 325 academics by employing diverse modes of communication such as e-mail and the post. The total of final suitable questionnaires was 256. Collected data was analyzed by using the software SPSS version 19.0. The analysis included descriptive and regressionanalysis.The results of the study revealedthat there is an overall level of satisfaction among academics and the work autonomy and recognition are the most vital determinants of job satisfaction. The findings indicated that there is a significant and joint impact between the independent variables and the job satisfaction.
\end{abstract}

Keywords:Academics, Job Satisfaction, Pay, Recognition, Work Autonomy, Working Environment, Workload

\section{Introduction}

Job satisfaction is the crucial determinantand isstrongly related to academics'intentions for entering higher education, which evidently shaped opportunities and attitudes to work. Mostacademics expressed their satisfaction on work, and their feelings towards involvement in the higher education process enhanced their important contribution to society. Job satisfaction is a particular view of the work with which employees view their job and this view is affected by favorable and unfavorable feelings and attachments of one's work (Newstrom,2007).Therefore, itis determined by several determinants such as economic factors, structural factors as well as psychological factors (Coomber andBarriball, 2007). The decision of an employee on whether to stay or to leave is directly affected by job satisfaction (Chen, et al. 2011).

As of the energetic environmental background, the density and inconsistency of society as a reaction to globalization, job satisfaction among academics is a necessity to make ongoing modifications if they are to be appropriate to Sri Lankan needs. Unfortunately, lesser devotion has been given to studying job satisfaction among academics in Sri Lankan public universities, comparing with other developing countries. As a result, the problem of this study could be identified as: What are the determinants that influence thejob satisfactionamong management faculty academics?

The objectives of this study are to examinethe determinantsof job satisfaction among academics, the level of job satisfaction among academics and investigating whether all independent variables have a significant joint impact on the job satisfaction among academics.

Job satisfaction

\section{Literature Review}

Spector (2003) defines job satisfaction as "the extent to which people like their job". According to Weiss (2002),job satisfaction is an attitude toward one's job resulting from the net sum of the individual's positive and negative emotions experienced at work.

Pay

Gerber , et al., (2003) noted that people perceive their pay as an indication of what they are worth to the organization. Previous findings(Saba, 2011; Souza-Poza 2000) reported that a constructive relationship has constantly been found between pay and job satisfaction. Pay has become one of the determinants that leads to a low or high job satisfaction in the academic setting in developed countries around the world (Scott, et al.,2003; VandenBerg, 2002; Zembylas and Papanastasiou, 2004). Based on the above facts this study formulates the first hypothesis as:

H1: Pay will influence job satisfaction among academics.

DOI: $10.9790 / 487 X-181005130134$

www.iosrjournals.org

$130 \mid$ Page 


\section{Work Load}

Khurum, et al., (2010) surveyed 107 faculty members of public sector universities and found that job satisfaction can be achieved through an attractive compensation plan and managing work load.Previous researchers (Chimanikire,et al.,2007;Santhapparaj and Alam 2005)discovered that workload had a great effect on the job satisfaction of academics. However, Altaf and Awan (2011) and Zainuddin, et al.,(2010) identified a negative relationship between workload and job satisfaction among academics. After studying the above evidence this study developed the second hypothesis as:

H2: The work loadwill influence job satisfaction among academics.

\section{Recognition}

Employee recognition is a return on an employee's effort, dedication at work and results. According to Herzberg, et al.,(1959) recognition is an intrinsic factor that can positively affect the job satisfaction of academics. Therefore, recognitionis said to be one of the most frequently used elements cited as a cause of satisfaction or dissatisfaction in employees (Locke, 1976).

Hence, the third hypothesis of this study was as follows:

H3: The recognition will positively relate to job satisfaction.

\section{Work Autonomy}

Castillo and Cano (2004) analyzed that content factors are the principle contributors in job satisfaction among faculty members and the facet "work itself" was the most satisfying attribute found in study while working condition was found to be the least satisfying aspect of the job. Employees tend to prefer jobs that give them opportunities to use their skills and abilities and which offer a variety of tasks, freedom and feedback on how well they are performing(Malik,2011;Robbins, 2005).Thus,hypothesis four was developed as follows:

H4: The work autonomy will positively affect job satisfaction.

\section{Working Environment}

Working environment has been recognized as a key factor influencing job satisfaction (Thompson and Jonas, 2008). Employees and working environment fit is the degree of compatibility or job satisfaction between an employee and his or her work environment (Bowling and Hammond, 2008;Kristof, 2006).Considering the above facts the last hypothesis of this study was develop as follows:

H5: The working environment will influence job satisfaction.

\section{Conceptual Framework}

Considering the existing literature, the conceptual framework of this study is depicted in Figure 1. Job satisfactionis labeled as the dependent variableandthe independent variable consists of the determinants of job satisfaction such as pay, workload, recognition, working environment and work autonomy.

Figure1: Conceptual Framework

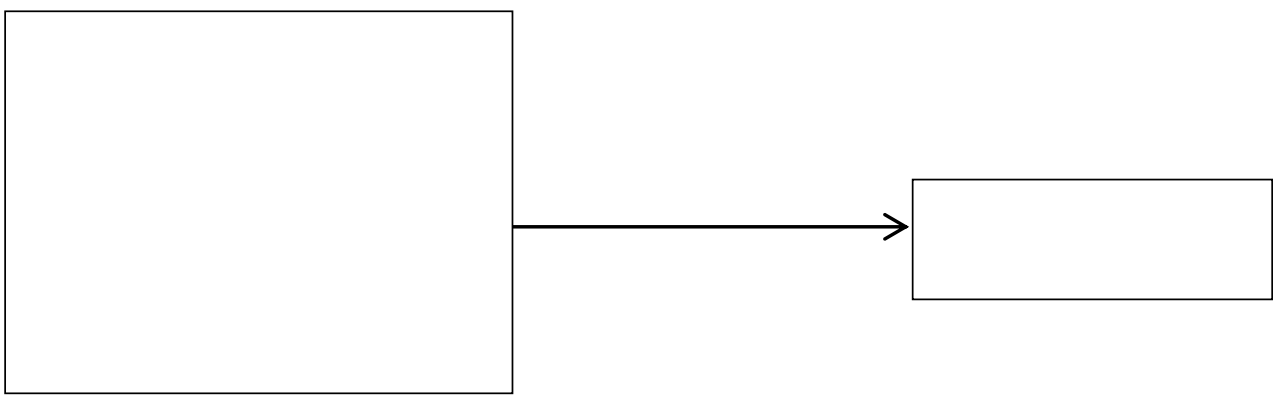

\section{Methodology}

A descriptive research design with a survey method is applied in the study. The type of investigation of this study was correlational because this study attempted to analyze the relationship between the dependent and the independent variables. As a result, this study was analytical in nature. A self-administered questionnaire was used to collect data. Hence the researchers' interference on the normal flow of events was minimal.

\section{Sample}

This study considered the simple random sampling technique and the population of the study consisted ofManagement Faculty Academics in three selected public universities in the Western Provinceand the number 
was 325. The structured questionnaire was e-mailed to all selected academics. Unit of analysis was at individual level.

\section{Measures}

This study considered demographic factors such as designation, gender, age, marital status, educational qualifications, salary andexperience.The determinants of job satisfaction measured through the short form of Minnesota Satisfaction Questionnaire (MSQ) were originally developed by Weiss et al. (1967). Job satisfaction was assessedbyusing the questionnaire of Schleicher,et al. (2004).Each variable was measured using a previously developed instrument with a 5-point Likert scale for all the measurements used ranging from (1) strongly disagree to (5)-strongly agree.

\section{Data Analysis}

Collected data were analyzed using Statistical Package for Social Science (SPSS 19).The results of the pilot study (30 academics)indicate that the Cronbach "sAlpha for all the dimensions of the study was greater than 0.7 which is adequate for the acceptable level.

Table 1:Reliability of the Constructs

\begin{tabular}{|l|l|l|}
\hline Dimensions & No: of Statements & Cronbach Alpha \\
\hline Pay (P) & 6 & 0.768 \\
\hline Workload (WL) & 5 & 0.856 \\
\hline Recognition (R) & 5 & 0.831 \\
\hline Working Environment (WE) & 7 & 0.827 \\
\hline Work Autonomy (WA ) & 5 & 0.735 \\
\hline Job Satisfaction (JS) & 6 & 0.871 \\
\hline
\end{tabular}

Considering the demographic factors the distribution of male and female staff is similar and a majority (64.1\%)is 30 to 50 years of age. Monthly salary saw a majority get more than Rs. 100,000.Majority of academics were married. In respect of the current working status, a majority are in the Senior Lecturer grade (Grade 11).

\section{Results from Regression Analysis}

Table 2: Descriptive statistics are the correlation between the constructs

\begin{tabular}{|l|l|l|l|l|l|l|l|l|}
\hline & Mean & Std. Deviation & JS & P & WL & R & WE & WA \\
\hline JS & 3.85 & .65 & 1.000 & .306 & & & & \\
\hline Pay & 2.6354 & .75774 & .306 & 1.000 & & & & \\
\hline Work load & 2.9872 & .76380 & .453 & .337 & 1.000 & & & \\
\hline Recognition & 3.4815 & .60971 & .482 & .103 & .315 & 1.000 & & \\
\hline Work environment & 2.7179 & .75780 & .438 & .228 & .321 & .329 & 1.000 & \\
\hline Work autonomy & 3.8772 & .59071 & .538 & .199 & .311 & .492 & .290 & 1.000 \\
\hline
\end{tabular}

$5 \%$ significance level

Based on Table 2 the overall mean value of the academics'satisfaction is 3.8 which isclose to 4 . Accordingly the lowest to the highest mean value of the determinants of job satisfaction are pay, working environment, work load, recognition and work autonomy.

Results from the multiple regression analysis of job satisfaction upon pay, work load, recognition, working environment and work autonomy are shown in Table 3.

Table 3: The Results from Regression Analysis

\begin{tabular}{|c|c|c|c|c|c|c|}
\hline \multirow[t]{2}{*}{ Model } & \multicolumn{2}{|c|}{ Unstandardized Coefficients } & Standardized Coefficients & \multirow[t]{2}{*}{$\mathrm{t}$} & \multirow[t]{2}{*}{ p-value } & \multirow[b]{2}{*}{ VIF } \\
\hline & $\mathrm{B}$ & Std. Error & Beta & & & \\
\hline (Constant) & .354 & .168 & & 2.100 & .036 & 1.164 \\
\hline Pay & .092 & .031 & .104 & 2.878 & .004 & 1.299 \\
\hline WE & .139 & .033 & .151 & 3.948 & .000 & 1.430 \\
\hline WL & .156 & .043 & .136 & 3.385 & .001 & 1.222 \\
\hline $\mathrm{R}$ & .195 & .032 & .215 & 5.781 & .000 & 1.403 \\
\hline WA & .486 & .044 & .431 & 11.096 & .000 & \\
\hline a. Dependent I & able: J & & & & & \\
\hline
\end{tabular}

In Table 3, the p-value for all the predictors is less than 0.05. Hence, JS depends on pay, work load,recognition,working environment and work autonomy. The R-square value was 0.556 . This means about $55 \%$ of the variation in JS is explained by pay, work load,recognition,working environment and work autonomy. The highest VIF value is less than 5. Hence, there is no problem of multi-collinearity. In the residual plot, all the points were within \pm 3 and were distributed randomly. The residuals were symmetrical around the value of 0 . 
The equation: $\mathrm{JS}=0.354+0.092 \mathrm{P}+0.139 \mathrm{WE}+0.195 \mathrm{R}+0.156 \mathrm{WL}+0.486 \mathrm{WA}$

For pay, for every unit increase in the perceived score, JS increases by 0.092 . For WE, for every unit increase in the perceived score, JS increases by 0.139 . For R for every unit increase in the perceived score, JS increases by 0.156 . For WL, for every unit increase in the perceived score, JS increases by 0.195 . For WA, for every unit increase in the perceived score, JS increases by 0.486 .

Based on the standardized coefficients in Table 3, the most important determinant of JS is WAand the least important one is pay. Other determinants (recognition, work load and work environment)arein between. Further, all the hypotheses of the study are accepted (refer Table 3).

Multiple regressions are shown in Table 4.

Table: 4 Combined Impact of the five determinants on JS

\begin{tabular}{|c|c|c|c|c|c|c|c|c|c|}
\hline \multirow[t]{2}{*}{$\mathrm{R}$} & \multirow[t]{2}{*}{ R Square } & \multirow{2}{*}{$\begin{array}{l}\text { Adjusted R } \\
\text { Square }\end{array}$} & \multirow{2}{*}{$\begin{array}{l}\text { Std. Error of the } \\
\text { Estimate }\end{array}$} & \multicolumn{5}{|c|}{ Change Statistics } & \multirow{2}{*}{$\begin{array}{l}\text { Durbin- } \\
\text { Watson }\end{array}$} \\
\hline & & & & $\begin{array}{l}\text { R Square } \\
\text { Change }\end{array}$ & F Change & df1 & df2 & Sig. F Change & \\
\hline .746 & .556 & .543 & .42674 & .014 & 5.188 & 1 & 164 & .024 & 2.138 \\
\hline \multicolumn{10}{|c|}{ Predictors: (Constant), P,WE,R,WL,WA } \\
\hline \multicolumn{10}{|c|}{ Dependent Variable: JS } \\
\hline
\end{tabular}

According to Table 4, the adjusted R-Square value is 0.543 , which means $54 \%$ of the variation in JScan be explained by five independent determinants (pay, work load, recognition, working environment and work autonomy). The Durbin-Watson statistic is 2.138 . This is close to residual series.

\section{Discussion and Conclusion}

Based on Table 2 the overall mean value of the academics' satisfaction is 3.8 which isclose to 4 . Therefore, the academics are satisfied. Accordingly, the lowest to the highest mean value of the determinants of job satisfaction are pay, working environment, work load, recognition and work autonomy. All the hypotheses of the study are accepted.Further,findings indicated that there is a significant and joint impact between the independent variables and the job satisfaction. So policy makers and academic administrators should take necessary steps to improve the lowest determinants of the job satisfaction and motivate as well as satisfy academics to achieving targets of the higher education system.

\section{References}

[1]. Altaf, A., and Awan, M. (2011).Moderating Affect of Workplace Spirituality on the Relationship of Job Overload and Job Satisfaction. Journal Of Business Ethics, 104(1), 93-99.

[2]. Bowling, N., and Hammond, G. D. (2008). A meta analytic examination of the construct validity of the Michigan Organisational Assessment Questionnaire Job Satisfaction. Journal of Vocational Behaviour., 63-77.

[3]. Castillo, J. X., Cano, J., and Conklin, E. A. (1999).Job satisfaction of Ohio agricultural education teachers. Journal of Agricultural Education 45(2), 19-27.

[4]. Chen, S. H., Yang, C. C., Shiau, J. Y., and Wang, H. H. (2011). The development of an employeesatisfaction model for higher education. The TQM Magazine, 18(5), 484-500.

[5]. Chimanikire, P., Mutandwa, E., Gadzirayi, C. T., Muzondo, N., and Mutandwa, B. (2007). Factors affecting job satisfaction among academic professionals in tertiary institutions in Zimbabwe. African Journal of Business Management, 1(6), 166-175.

[6]. Coomber, B., andBarriball, L. K. (2007). Impact of job satisfaction components on intent to leave and turnover for hospital-based nurses: a review of the research literature. International Journal of Nursing Studies, 44, 297-314.

[7]. Herzberg, F., Maunser, B., and Snyderman, B. (1959). The motivation to work. New York, NY, John Wiley and Sons, Inc.

[8]. Kristof, B. A. (2006). Towards a multi dimensional theory of P-E fit. . Journal of Managerial Issues, 47(7), $246-576$.

[9]. Locke, E. A. (1976). The nature and causes of job satisfaction", in Dunnette, M.D. (Ed.),Handbook of Industrial and Organizational Psychology. Chicago: Rand McNally.

[10]. Malik, N. (2011). A Study on Job Satisfaction Factors of Faculty Members at the University of Balochistan. Journal of Research in Education 2(2).

[11]. Newstrom, J. W. (2007). Organizational Behaviour-Human Behaviour at work (12th ed). New York: McGraw Hill International Edition.

[12]. Robbins, S. P. (2005). Essentials of Organisational Behavior. New Jersey: Pearson.

[13]. Saba, I. (2011). Measuring the job satisfaction level of the academic staff in Bahawalpur colleges. International Journal of Academic Research in Business and Social Sciences, 1(1), 12-19

[14]. Santhapparaj, A. S., and Alam, S. S. (2005). Job satisfaction among academic staff in private universities in Malaysia. Journal of Social Sciences, 1(2), 72-76.

[15]. Schleicher, D.J., Watt, J.D. andGreguras, G.J. (2004).Re-examining the job satisfaction-performance relationship: The complexity of attitudes. Journal of Applied Psychology, 89, 165-177.

[16]. Scott, T.M., Parveen, S., Portier, K.M., Rose, J.B., Tamplin, M.L., Farrah, S.R., Koo, A. and Lukasik, J. (2003) Geographical variation in ribotype profiles of Escherichia coli isolates from humans, swine, poultry, beef, and dairy cattle in Florida. Appl. Environ. Microbiol. 69, 1089-1092.

[17]. Sousa-Poza, A., and Sousa-Poza, A. A. (2000). Well-being at Work A Cross- National Analysis of the Levels and Determinants of Job Satisfaction. J. Socio-Economics, 12, 517-538. 
[18]. Spector, P.E. (2003). Job Satisfaction: Application, assessment, causes and consequences. Thousand Oaks, CA: Sage Publications, Inc.

[19]. Thompson, B., and Jonas, D. (2008). Workplace Design and Productivity: Are They Inextricably Linked?, Royal Institute Charter of Surveyors, London.

[20]. Vandenberghe, C., and Trembley, M. (2008). The Role of Pay Satisfaction and Organizational Commitment in Turnover Intention: A Two Sample Study. Journal of Business Psychology, 22, 275-286.

[21]. Weiss, H. M. (2002). Deconstructing job satisfaction: separating evaluations, beliefs and affective experiences. Human Resources Management Review, 12(2), 173-194

[22]. Zainudin, A., Junaidah, H. A., and Nazmi, M. Z. (2010). Modelling job satisfaction and work commitment among lecturers: a case of UITM kelantan. Journal of Statistical Modeling and Analytics, 1(2), 45-59.

[23]. Zembylas, M. and Papanastasiou, E. (2004). "Job satisfaction among school teachers in Cyprus", in Journal of Educational Administration, 42, 3: 357-374. 